\title{
STIGMA DAN KRIMINALITAS : STUDI KASUS STIGMA DUSUN BEGAL DI BANGKALAN MADURA
}

\author{
Fitria Dayanti ${ }^{1}$, Martinus Legowo
}

Universitas Negeri Surabaya

fitria.19021@mhs.unesa.ac.id

\begin{abstract}
ABSTRAK
Adanya tindakkriminal begal di sebuah daerah membawapengaruhburukpadadaerah tersebut. Kasus kriminal begal yang terjadi di Dusun Candih membawa permasalahan baru pada nama baik dan citra Dusun. Stigma dan pelabelan buruk mulai bermunculan pada dusun tersebut. Studi ini memfokuskan pada bentuk-bentuk stigma yang diterima oleh Masyarakat Dusun Candih, serta respon dari masyarakat atas stigma yang diberikan. Penelitian ini menggunakan metode kualitatif desk riptif dengan subjek penelitian yakni tetuahdusun danmasyarakat asli Dusun Candih. Teori yan g digunakan dalam penelitian ini adalah teori stigma dari Erving Goffman. Teknik pengumpulan data dilakukan dengan dengan wawancara mendalam, observasi lapangan, dan dokumentasi. Teknik analisis data yang digunakan adalah analisis interaktif dengan langkah reduksi data, penyajian data, dan penarikan kesimpulan. Hasil daripenelitian ini yakni bentuk-bentukstigma yang diterima olehmasyarakat Dusun Candih. Stigma yang ada bersifat verbal dan non verbal. Stigma verbal berupa julukan atau pelabelan pada dusun yakni julukan "Dusun Begal”. Sedangkan stigma non verbal berupa anggapan bahwa semua masyarakat Dusun Candih merupakan pelaku begal yang identik dengan kejahatan dan tindak kriminal. Selain itu stigma non verbal jugamenga rah padapandangan yang merendahkan atau bahkan menjelek-jelekkan masyarakat Dusun Candih.
\end{abstract}

Kata Kunci: Stereotipe, Begal, Masalah Sosial

\begin{abstract}
The existence of criminal acts of robbery in an area has a bad influence on the area. The criminal case of robbery that occurred in Candih Hamlet brought new problems to the good name and image of the Hamlet. Stigma and bad labeling began to emerge in the village. This study focuses on the forms of stigma received by the Candih Hamlet community, as well as the response from the community to the stigma given. This study uses a descriptive qualitative method with the research subjects of village elders and the indigenous people of Candih Hamlet. The theory used in this research is Erving Goffman's stigma theory. Data collection techniques were carried out by in-depth interviews, field observations, and documentation. The data analysis technique used is interactive analysis with steps of data reduction, data presentation, and drawing conclusions. The results of this study are the forms of stigma that are accepted by the people of Candih Hamlet. The existing stigma is verbal and non-verbal. Verbal stigma in the form of nicknames or labeling in the hamlet is the nickname "Dusun Begal". Meanwhile, non-verbal stigma is in the form of the assumption that all Candih Hamlet people are
\end{abstract}

Korespondensi:

Universitas Negeri Surabaya

Jl. Lidah Wetan, Lidah Wetan, Kec. Lakarsantri, Kota

SBY, Jawa Timur 60213

JURNAL ILMIAH DINAMIKA SOSIAL 5 (2) $2021 \mid 277$

E-mail: (fitria.19021@mhs.unesa.ac.id) 
criminals who are synonymous with crime and crime. In addition, non-verbal stigma also leads to views that demean or even vilify the Candih Hamlet community.

Keywords: Stereotype, Robber, Social Problems

\section{PENDAHULUAN}

Tindakan individu memiliki batasan di dalam kehidupan sosial. Semua tindakan yang ada dibatasi oleh aturan untuk berbuat dan berperilaku (Formaninsi, 2014). Tidak hanya aturan secara tertulis, aturan implisit seperti norma turut menentukan baik buruknya sebuah tindakan. Dengan adanya aturan dan norma tersebut, perilaku manusia dibatasi dan harus meyesuikan pada apa yang telah dianggap baik oleh masyarakat. Manusia harus berperilaku sesuai dengan nilai yang telah disepakati dalam sebuah sistem sosial. Namun demikian, di tengah kehidupan masyarakat masih ditemui tindakan-tindakan yang tidak sesuai dengan aturan atau norma. Tindakan yang tidak sesuai dengan nilai dan norma yang berlaku dalam kehidupan masyarakat biasanya disebut sebagai penyimpangan sosial (Tola \& Suardi, 2017). Penyimpangan yang dilakukan disebut sebagai deviasi, sedangkan pelaku dari penyimpangan disebut sebagai devian.

Penyimpangan menjadi bagian dari masalah sosial karena berkaitan dengan pelanggaran norma. Segala sesuatu dianggap sebagai masalah sosial karena menyangkut relasi antara manusia dengan nilai-nilai dalam kehidupan masyarakat (Tola \& Suardi, 2017). Masalah sosial atau social problems sendiri diartikan sebagai sebuah keadaan yang dianggap sebagai ancaman oleh masyarakat dan keberadaannya tidak dikehendaki (Soyomukti, 2014). Hal ini dikarenakan besar kecilnya suatu penyimpangan tentu akan menimbulkan terganggunya keseimbangan kehidupan dalam masyarakat. Perilaku meresahkan atau masalah sosial kini telah menjadi hal yang krusial dalam kehidupan masyarakat. Jika harapan dan kenyataan yang ada mengalami perbedaan atau kesenjangan dari situasi yang seharusnya terjadi, maka hal itu dapat disebut sebagai masalah sosial. Masalah sosial berkaitan erat dengan adanya disorganisasi sosial (Hajas, 2019). Umumnya, disorganisasi sosial ditandai dengan adanya perubahan-perubahan yang cepat dalam kehidupan sosialnya. Jika tidak ada pengalaman dan pengetahuan untuk menghadapi perubahan tersebut maka akan menimbulkan suatu problematika baru.

Banyak faktor yang menyebabkan manusia melakukan penyimpangan seperti melakukan tindak kejahatan. Yang menjadi poin besar dari pendorong seseorang melakukan tindak kejahatan adalah tidak terpenuhinya keinginan atau kebutuhan dalam menjalani kehidupan bermasyarakat. Thomas Van Aquino (1274), menyatakan bahwa tindak kejahatan 
yang dilakukan oleh seseorang disebabkan oleh kemiskinan yang dialami. Pernyataan serupa ditemukan dalam penelitian yang dilakukan Muhammad (2015), ada beberapa faktor yang mendorong sseorang untuk melakukan kejahatan yakni adanya faktor lemahnya penegakan hukum, faktor lingkungan, faktor pendidikan, dan faktor ekonomi. Terlihat jelas bahwa jika manusia tidak memiliki kemampuan untuk memenuhi kebutuhannya maka ia akan menggunakan segala cara untuk dapat memenuhinya. Kemelaratan yang dialami akan mendorong orang tersebut untuk berbuat kejahatan atau kriminal seperti adanya pembegalan (Millah, 2020). Begal sendiri dalam kamus bahasa Indonesia diartikan sebagai perampok atau perampas. Secara sederhana, begal atau membegal didefiniskan sebagai sebuah tindakan merampas harta benda orang lain yang bisa disertai dengan kekerasan atau ancaman yang dilakukan di jalan (Tola \& Suardi, 2017).

Suatu hal menarik, begal sebagai kejahatan konvensional justru telah menjadi sebuah fenomena kejahatan yang sampai saat ini masih meresahkan masyarakat Indonesia, tak terkecuali di wilayah Bangkalan Madura. Daerah Bangkalan Madura terkenal dengan tindak kejahatan begal (Ramadhan, 2020). Sudah bukan menjadi rahasia umum, bahwa di daerah Bangkalan Madura sampai saat ini masih sering terjadi kasus kriminal begal. Data begal di Bangkalan, menunjukkan bahwa sepanjang tahun 2018 hingga 2021 telah banyak terjadi kasus kejahatan begal. Bahkan akhir-akhir ini pihak kepolisian setempat gencar melakukan operasi penangkapal begal. Seperti berita yang telah dikutip oleh Tribunmadura.com, mengungkapkan bahwa polisi telah mengamankan beberapa oknum tindak kejahatan begal yang beroperasi di area sekitar Universitas Trunojoyo Madura. Ada beberapa titik lokasi yang kerap kali menjadi lokasi pembegalan yakni di Dusun Candih hingga masuk ke area kampus UTM. Terkait lokasi pembegalan, dalam melaksanakan aksinya pelaku begal biasanya menentukan daerah yang sepi dan kriteria-kriteria tertentu (Andina, 2015). Dusun Candih sebagai lokasi yang biasanya digunakan untuk melakukan aksi begal memang terbilang sepi. Sepanjang jalan tersebut jarang dijumpai rumah warga dan kebanyakan hanyalah lahan kosong untuk pertanian. Karakteristik tersebut yang kemudian dimanafaatkan oleh pelaku begal untuk melakukan aksinya.

Apabila perilaku yang ditunjukkan merugikan orang lain, maka pelakunya pasti memperoleh sanksi sosial dari masyarakat (Ricardo, 2010). Sanksi sosial yang diberikan bisa berupa guncingan, cemoohan, atau bahkan pelabelan atau stigma. Tak hanya pelaku, keluarga atau kerabat dekat saja bahkan desa tempat pelaku menjalankan aksinya juga terkena dampaknya. Berkaitan dengan kejahatan begal yang terjadi, stereotip yang muncul adalah pada 
Dusun Candih sebagai lokasi yang biasanya terjadi aksi pembegalan. Dengan rawannya daerah tersebut sebagai lokasi tindak kejahatan begal akhirnya berakibat pada munculnya stereotip yang buruk terhadap masyarakat di dusun tersebut. Stereotip yang diberikan memang menunjukkan adanya reaksi dari masyarakat luas pada aksi pembegalan yang terjadi. Benar adanya jika stereotip diberikan kepada pelaku, akan tetapi menjadi kesalahan apabila masyarakat umum yang tidak melakukan tindak kejahatan juga terkena dampaknya. Masyarakat umum yang hanya menjadi penduduk dari dusun lokasi pembegalan juga turut diberi label buruk. Tentu hal ini akan berdampak pada tatanan kehidupan dan sistem sosial masyarakatnya.

Seharusnya stereotip tersebut tidak diberikan kepada warga atau dusun Candih. Sebab, berdasarkan penelitian yang dilakukan oleh Ramadhan, (2020) bukan warga di dusun tersebut yang melakukan tindak kejahatan begal melainkan oknum-oknum tertentu yang berasal dari daerah lain. Stigma yang telah diberikan tentu akan menimbulkan masalah-masalah baru pada tatanan kehidupan masyarakat Dusun Candih. Masyarakat Dusun Candih telah tersigma oleh perbuatan yang bahkan tidak mereka lakukan. Maka dari itu, penelitian ini dilakukan untuk mengetahui bentuk-bentuk stigma serta menganalisa dampak-dampak pemberian stigma pada tatanan kehidupan masyarakat Dusun Candih.

\section{KAJIAN TEORI}

Penggunaan teori pada penelitian digunakan sebagai pisau analisis dari setiap permasalahan yang dihadapi. Teori juga digunakan sebagai alat untuk menganalisis data yang diperoleh dari penelitian. Selain itu, teori juga membantu pembentukan kerangka pemikiran terhadap penelitian. Pada penelitian ini menggunakan pisau analisis teori stigma dari Erving Goffman. Goffman (1963), memberikan pengertian bahwa stigma adalah atribut yang merusak citra diri seseorang dan membawa pengaruh besar pada kepribadian seseorang dan akhirnya membuatnya tidak bisa berperilaku seperti biasanya. Stigma yang diberikan berupa tanda yang dibuat dengan tujuan untuk memperlihatkan atau menginformaskan kepada masyarakat bahwa orang-orang yang memiliki tanda tersebut merupakan seseorang yang memiliki perbedaan atau berperilaku menyimpang, seperti penjahat, pelaku kriminal, budak, pengkhianat dan semacamnya. Sehingga stigma ini cenderung mengacu pada atribut yang memperburuk citra seseorang. Oleh karena itu adanya istilah stigmatisasi dapat dipahami sebagai proses kehilangan identitas sosial masyarakat sehingga diasingkan atau dikucilkan oleh pergaulan hidup yang ada. 
Goffman menyebutkan bahwa apabila seseorang memiliki atribut yang berbeda dengan orang-orang pada umumnya, maka dia akan diasumsikan sebagai orang yang ternodai, buruk, berbahaya, dan lemah (Goffman, 1963). Atribut itulah yang dipahami sebagai stigma. Stigma yang ada dapat mengurangi identitas sosial seseorang dari penerimaannya dalam lingkungan sosial. Dalam teorinya, Erving Goffman menjelaskan kaitan antara self dan identity yang dimulai dari dirinya sendiri. Konsep self menurutnya diperoleh melalui proses interaksi individu dengan lingkungan sosialnya, yang kemudian merambah pada proses pembentukan identitas. Konsep pembentukan identitas ini menjadi konsep utama dari lahirnya pemikiran tentang stigma (Ayunani, 2016). Goffman (1963), memberikan penjelasan tentang konsepkonsep stigma sebagai berikut :

1. Self

Self berhubungan dengan diri individu. Yang diamati adalah bagaimana seorang individu tersebut melihat atau memaknai dirinya sendiri serta bagaimana orang lain memandang dirinya. Pemaknaan tersebut terbentuk oleh adanya proses interaksi yang dilakukan dengan individu lain dalam kehidupan sosialnya. Dengan hal tersebut maka orang lain dapat mempengaruhi dalam pengkontruksian akan konsep diri dari seorang individu.

\section{Identity}

Erving Goffman membagi identitas berdasarkan dua cara pandang yakni virtual social identity dan actual social identity. Virtual social identity merupakan sebuah identitas yang terbentuk dari karakter-karakter yang diasumsikan pada seseorang yang kemudian dikenal sebagai karakterisasi. Sedangkan actual social identity merupakan identitas yang terbentuk dari karakter-karakter yang terbukti keberadaannya (Goffman, 1963). Orang-orang yang memiliki celah diantara dua identitas tersebut yang nantinya akan distigmatisasi. Stigma yang ada lebih memfokuskan pada interaksi dramaturgis diantara orang yang terstigmatisasi dengan orang yang normal. Selain itu, Goffman juga memberikan dua konsep tentang identitas yakni personal identity dan self identity. Personal identity biasanya ada pada pembingkaian tentang pengalaman yang dialami oleh orang lain yang kemudian diidentifikasi. Hal ini mengarah pada berbagai karakteristik serta fakta-fakta yang ditempatkan pada pikiran individu, seperti contoh bagaimana foto seorang individu mampu menampilkan image atau pandangan tertentu dalam pikiran orang lain. Sedangkan self identity lebih dikaitkan pada perasaan 
subyektif dalam diri seseorang dari situasi yang dialaminya. Self identity dari seorang individu dapat dikatakan berkaitan erat dengan pengalaman-pengalaman sosial yang mereka alami. Menurut Goffman (1963), seorang individu mengonstruksikan image yang ada dalam dirinya seperti apa yang dikonstruksikan oleh orang lain, meskipun ia memiliki kebebasan untuk mengidentifikasi dirinya.

Goffman membagi stigma menjadi tiga tipe, meliputi :

1. Stigma terhadap kecacatan pada tubuh. Stigma ini terbentuk karena adanya kecacatan pada tubuh yang dimiliki oleh seseorang yang akhirnya dianggap sebagai sebuah perbedaan dengan masyarakat pada umumnya.

2. Stigma terhadap buruknya perilaku seseorang. Stigma ini cenderung diberikan kepada orang-orang yang melakukan kejahatan yang biasanya dilihat dari sudahnya seseorang masuk ke dalam penjara, meminum alkohol, atau orang yang memiliki kesehatan mental buruk.

3. Tribal stigma. Stigma ini diberikan kepada keadalm kelompo yang mana seseorang di dalamnya memiliki afiliasi.

Berkaitan dengan judul penelitian Stigma dan Kriminalitas yang terjadi di Dusun Candih, Kamal, Bangkalan, peneliti menggunakan gagasan fikiran Erving Goffman dalam teori stigmanya. Berdasarkan konsep di atas, pemberian label atau stigma lebih difokuskan pada masyarakat Dusun Candih secara umum. Masyarakat luar memberikan stigma karena Dusun Candih dijadikan sebagai lokasi pembegalan, sehingga masyarakat umum menganggap bahwa dusun tersebut dihuni oleh orang-orang yang bertindak kriminal. Pemberian label yang diterima masyarakat Dusun Candih menjadi permasalahan sosial sebab dengan label tersebut berdampak buruk bagi tatanan dan kehidupan sosial masyarakatnya. Maka dari itu, bentukbentuk stigma dan dampak yang dirasakan oleh masyarakat Dusun Candih akan lebih difokuskan dalam penelitian ini dibandingkan pada pemberian stigma yang dialami oleh pelaku tindak kriminal begal.

\section{METODE PENELITIAN}

Jenis penelitian yang digunakan adalah penelitian kualitatif deskriptif. Penelitian kualitatif ini bertujuan untuk memberikan gambaran atau uraian tentang dinamika stigamtisasi yang dialami oleh masyarakat. Creswell (2008) mendefinisikan metode kualitatif sebagai sebuah pendekatan yang bertujuan untuk mengeksplorasi dan memahami secara mendalam suatu gejala sosial (Sadewo, 2016). Peneliti menggunakan metode tersebut sebab penelitian ini 
bertujuan untuk mendeskripsikan kondisi yang terjadi, menjelaskan peristiwa, serta menjawab pertanyaan tentang stigma yang terjadi setelah adanya tindak kriminal begal di Dusun Candih. Penelitian ini dilakukan di dusun Candih, Desa Gili Timur, Kecamatan Kamal, Kabupaten Bangkalan. Adapun alasan peneliti memilih lokasi tersebut sebab Dusun Candih merupakan dusun yang kerap kali dijadikan sebagai lokasi pembegalan. Sehingga munculnya pelabelan dan stigma yang diberikan oleh masyarakat luar pada Dusun tersebut. Maka dari itu lokasi tersebut dipilih karena dirasa tepat untuk mendapatkan data yang dicari tentang stigma dari tind akan kriminal.

Secara umum terdapat dua jenis data yang digunakan dalam penelitian ini yakni data primer dan data sekunder. Data yang dibutuhkan akan dicari menggunakan beberapa teknik pengumpulan data yakni observasi, wawancara, dan dokumentasi. Tahap observasi dikumpulan dengan melakukan pengamatan langsung di lokasi penelitian dengan melihat bagaimana kegiatan sehari-hari masyarakat Dusun Candih dalam kehidupan bermasyarakat. Teknik pengumpulan data selanjutnya adalah wawancara. Teknik ini dilakukan dengan proses tanya jawab antara peneliti dengan informan terkait yakni masyarakat yang bertempat tinggal di Dusun Candih seperti tetuah dusun, blater desa, dan masyarakat umum sebagai informan pendukung. Karena penelitian ini dilakukan di masa pandemi maka dalam proses wawancara akan dilakukan dengan dua tahap yakni wawancara secara langsung di lokasi penelitian dan wawancara tidak langsung menggunakan platform WhatsApp. Hal ini dilakukan dengan menyesuaikan status Covid di Dusun Candih. Teknik pengumpulan data yang terakhir adalah dokumentasi. Teknik ini dilakukan dengan mengumpulkan dokumen-d okumen pendukung dari beberapa literatur untuk membantu peneliti untuk mengumpulkan data. Maka dari itu data primer dalam penelitian ini diperoleh dari tahap observasi dan wawancara. Sedangkan data sekunder diperoleh dari berbagai dokumentasi tertulis seperti artikel jurnal, buku, dan sumber lainnya yang selinier dengan tema penelitian.

Data yang telah diperoleh, selanjutnya akan dianalisis melalui tiga tahap. Tahap yang pertama yakni reduksi data. Pada tahap ini data yang telah diperoleh akan dipilih dan diseleksi sesuai dengan kebutuhan penelitian. Kemudian, tahap selanjutnya adalah penyajian data. Dalam tahap ini data yang telah dipilih akan disajikan melalui analisis narasi yang memungkinkan untuk mengungkapan kebutuhan penelitian. Terakhir, adalah tahap penarikan kesimpulan. Tahap ini dilakukan dengan menganalisa data yang ditelah peroleh dan kemudian ditarik kesimpulan. 


\section{PEMBAHASAN}

\section{Kriminal Begal di Dusun Candih}

Bangkalan merupakan salah satu kabupaten di Pulau Madura yang berbatasan langsung dengan kota Surabaya. Kasus begal di Bangkalan telah menjadi cerita lama yang melegenda. Hingga tahun ini pun kasus begal masih sering terjadi di wilayah Bangkalan. Kasus begal yang ada di Bangkalan sendiri terkenal sadis karena pelaku tidak segan untuk melukai bahkan membunuh korbannya (Ramadhan, 2020). Data statistik kasus pencurian kekerasan dan kasus begal yang dipeorleh dari Polres Bangkalan pada 08 Januari 2021, selama sepekan terdapat 7 kasus yang berhasil diungkap. Dua pelaku begal berhasil dibekuk yakni berinisal F (35) dan RA (40) warga Desa Parseh Kecamatan Socah, Bangkalan Madura (Humas.polri.go.id (2021)). Tak hanya itu dalam periode tahun 2018-2020, data kasus pembegalan yang terjadi di Bangkalan menunjukkan bahwa pada tahun 2018 terdapat 21 kasus begal yang terlapor dan terselesaikan sebanyak 17 kasus. Kemudian pada tahun 2019, terdapat 30 kasus begal yang terlapor dan yang terselesaikan sebanyak 26 kasus. Dan pada tahun 2020 terdapat kasus begal terlapos sebanyak 12 kasus dan terselaikan sebanyakl 10 kasus. Dari kasus-kasus di wilayah Bangkalan tersebut, banyak kasus pembegalan yang terjadi pada mahasiswa Universitas Trunojoyo Madura di Dusun Candih.

Dusun Candih merupakan dusun yang terletak di Desa Gili Timur, Kecamatan Kamal Kabupaten Bangkalan. Dusun tersebut berada pada sisi timur Kampus Universitas Trunojoyo Madura. Bagi mahasiswa yang berasal dari luar Madura (Surabaya) biasanya akan melewati dusun tersebut jika hendak pergi ke Kampus. Dusun tersebut memang memiliki jalan pintas dari Tol Suramadu ke Kampus UTM dan menjadi jalan alternatif utama yang banyak dilalui mahasiswa dan masyarakat umum. Jalan raya yang membentang lurus dari Kecamatan Labang sebagai Gerbang Tol Suramadu sisi Madura hingga ke Dusun Candih sebagai dusun terakhir sebelum Kampus UTM, memiliki manfaat tersendiri bagi masyarakat. Bagi Masyarakat umum dan mahasiswa, jalan raya tersebut sebagai akses tercepat untuk ke Kampus, sedangkan bagi oknum-oknum tindak kriminal jalan tersebut cocok untuk melakukan aksi kriminalnya (Hendriana et al., 2016). Lokasi tersebut yang cenderung sepi digunakan oleh oknum tindak kriminal untuk melakukan aksi pembegalan. Memang sepanjang jalan tersebut jarang ditemui rumah penduduk dan kebanyakan adalah lahan kosong yang digunakan untuk pertanian. Berdasarkan informasi yang beredar, sasaran utama aksi pembegalan adalah mahasiswa UTM yang berasal dari luar Madura seperti Surabaya dan sekitarnya, terbukti dengan bukti motor 
hasil curian yang berhasil diamankan rata-rata ber plat L yang menandakan dari Surabaya. Namun tidak menutup kemungkinan juga masih banyak motor dari daerah lain yang dicuri.

\section{Bentuk-Bentuk Stigma Masyarakat Dusun Candih}

Rawannya aksi pembegalan yang terjadi di Dusun Candih menimbulkan stigma dan pelabelan baru di masyarakat. Berkaitan dengan stigma, pada dasarnya orang-orang akan menginterpretasikan hal yang menyimpang atau tidak sesuai dengan norma seperti tindak kriminal begal. Interprestasi dari apa yang terjadi di Dusun Candih sebagai lokasi rawan begal, membuat masyarakat umum memaknai bahwa Dusun candih merupakan "Dusun Begal". Interpretasi ini yang pada akhirnya menimbulkan stereotip dan pelabelan khusus yang melekat pada Dusun Candih. Tak hanya itu dengan adanya pelabelan tersebut menyebabkan pemisahan diri 'kita' dan 'mereka' antara masyarakat lokal dengan masyarakat luar. Pemisahan tersebut yang biasanya akan menimbulkan adanya perilaku diskriminasi seperti pengucilan, gunjingan, dan lain sebagainya.

Masyarakat Dusun Candih baik yang terlibat dalam kasus kriminal begal maupun tidak, menerima berbagai bentuk stigma dari masyarakat sekitar. Adapun bentuk stigma yang diterima bersifat verbal dan non verbal. Stigma verbal yang diterima masyarakat Dusun Candih lebih kepada istilah atau julukan yang diberikan seperti julukan "Dusun Begal”. Adanya istilah yang beredar tersebut membuat masyarakat Dusun Candih di cap sebagai masyarakat yang identik dengan kejahatan sehingga keberadaannya harus dijauhi dalam kehidupan sehari-hari. Masyarakat di sekitar Dusun Candih seperti Desa Jukong, Labang, Sukolilo, Telang, Kamal, dan lain sebagainya mengkonstruksikan pelabelan tersebut sebagai sebuah antipasi akan adanya tindak kriminal agar mereka lebih berhati-hati saat melintasi Dusun tersebut. Sedangkan stigma non verbal yang terima masyarakat Dusun Candih lebih kepada penolakan yang diberikan pada warga asli dusun tersebut.

Terdapat informan yang menyatakan bahwa sering mendengar dan mendapatkan perlakuan negatif dari lingkungan pertemanannya dengan orang-orang luar. Di mana orangorang luar telah memberi label masyarakat di dusunnya sebagai orang-orang pelaku kriminal. Selain itu informan tersebut juga beranggapan bahwa banyak orang dari desa lain yang menyepelakan penduduk Dusun Candih dan menganggapnya sebagai orang jahat. Kemudian selain memberikan stigma pada penduduk didusun tersebut, orang luar dusun juga memberikan stigma atau prasangka negatif pada Dusun Candih itu sendiri. Stigma dan label yang diberikan cenderung bermakna menyepelekan, menjelekkan, serta memandang rendah. Dengan julukan 
'Dusun Begal', semua penduduk di dusun tersebut dianggap sebagai pelaku begal. Hal itu sebenarnya sudah banyak merugikan identitas asli dari penduduk dusun. Masyarakat luar belum bisa melihat realitas yang adabahwasanya tidak semua warga Dusun Candih melakukan tidak kriminal begal atau bahkan tidak sama sekali melakukan tindakan tersebut.

Pada saat salah satu informan pergi ke luar dusun dan berinteraksi dengan orang laur, ia pasti akan diberi pertanyaan apakah ia tidak takut jika berpergian keluar rumah atau jika pulang pada malam hari. Dari hal itu bisa dilihat bahwa kesan pertama seseorang dari luar Dusun Candih adalah tentang dusun yang sangat rawan jika dilintasi. Orang luar dusun merendahkan hingga akhirnya memberikan julukan sebagai "Dusun Begal". Sebutan begal sendiri sudah bisa menjatuhkan nama baik dari dusun tersebut karena begal selalu dikonotasikan sebagai perilaku kriminal yang tidak berperasaan dan selalui identik dengan perampasan dan bahkan pembunuhan. Padahal, dalam kenyataannya tidak menutup kemungkinan bahwa dusun dan desa lain juga melakukan tindak kriminal. Stigma yang diberikan pada masyarakat Dusun Candih sebenarnya tidak mengacu pada karakteristik tertentu, dalam artian bahwa stigma yang diberikan oleh masyarakat luar memang hanya berdasarkan sepengetahuan mereka saja bahwa Dusun Candih menjadi lokasi pembegalan. Sehingga stigma atau julukan yang diberikan lebih kepada ciri khas yang ditunjukkan oleh dusun tersebut.

\section{Dampak dan Respon Masyarakat Lokal Atas Stigma “ Dusun Begal ”}

Stigma yang melekat pada Dusun Cand ih sebagai "Dusun Begal" memberikan dampakdampak yang berarti pada kehidupan masyarakat. Kerugian-kerugian yang dirasakan oleh masyarakat Dusun Candih dari stigma tersebut sudah cukup meresahkan masyarakat. Salah satu kerugian yang dirasakan adalah merasa terhina dengan julukan yang ada. Stigma dan julukan yang diberikan membuat orang lain atau masyarakat luar memandang negatif pada Dusun Candih. Menurut penuturan salah satu informan, ia susah mendapatkan kepercayaan dari teman-teman kampusnya. Jika ia mengajak teman-temannya untuk bermain kerumahnya ia selalu mendapatkan penolakan karena adanya perasaan takut dari teman-temannya apabila melintasi dan bahkan datang ke dusun tersebut. Hal itu yang membuat dirinya kerap merasa kesal sehingga membutuhkan usaha lebih untuk memberikan penjelasan padateman-temannya tersebut.

Masyarakat Dusun Candih memberikan beragam respon dalam menanggapi stimulus negatif yang diberikan pada mereka. Dari keterangan beberapa informan, meskipun tempat 
tinggalnya diberi julukan "Dusun Begal", tetapi pada dasarnya warga asli dusun tersebut tidak melakukan aksi begal. Dapat dikatakan mereka yang terkena imbasnya hanya karena mereka tinggal di Dusun tersebut. Maka dari itu, mereka hanya bisa menerima julukan yang ada tanpa bisa berbuat apa-apa. Hal tersebut mereka terima selama warga dusunnya tidak melakukan aksi-aksi yang menyimpang. Warga Dusun Candih menganggap bahwa pelabelan "Dusun Begal" itu sebagai hal yang wajar, karena mengingat tempat mereka tinggal adalah lokasi aksi pembegalan terjadi. Label-label tersebut wajar adanya ketika terdapat sesuatu yang menyimpang dari norma dan nilai yang dianut masyarakat. Beberapa informan juga mengaku bahwa mereka tidak terlalu memusingkan label tersebut selama mereka sendiri tidak melakukannya. Mereka tetap menjalankan kehidupan sehari-hari sebagaimana mestinya tanpa menghiraukan pelabelan dan julukan yang ada, dengan tujuan untuk menjaga kesehatan mental mereka.

Stigma yang diberikan oleh masyarakat luar baik untuk warga atau untuk Dusun Candih secara keseluruhan, tergantung pada bagaimana masing-masing individu merespon dan menyikapi stigma tersebut. Adanya anggapan negatif dan postif pasti ada dalam kehidupan mereka sehari-hari, sehingga dalam hal ini perlu adanya sikap bijak dalam menghadapi persolan tersebut. Salah seorang informan mengatakan bahwa adanya prasangka dan julukan pada dusunnya membuat warga asli jarang mengalami kasus pencurian atau kemalingan. Menurutnya dengan ad anya label tersebut dusunnya menjadi aman karena disegani atau bahkan ditakuti oleh maling-maling dari luar yang biasanya mengincar sapi dan hewan ternak lainnya. Sehingga dalam hal ini kasus kemalingan yang ada di dusun tersebut tidak setinggi kasus yang dialami oleh dusun-dusun lainnya.

\section{Dusun Candih Dalam Perspektif Teori Stigma}

Adanya stigma yang melekat pada masyarakat Dusun Candih jika dianalisis menggunakan konsep stigma dari Erving Goffman, maka stigma dapat dilihat dari konsep self dan identity. Pada konsep self masyarakat Dusun Candih melalui interaksi yang ada dapat memaknai diri mereka sendiri. Interaksi yang terjadi antara masyarakat Dusun Candih dengan masyarakat luar mempengaruhi proses pemaknaan diri bagi masyarakat setempat. Dalam konsep self, masyarakat Dusun Candih memaknai diri mereka secara berbeda tentang adanya tindak kriminal begal. Di mana dusun-dusun lain yang ada di Desa Gili Timur tidak se rawan Dusun Candih tentang kasus pembegalan. Sehingga dalam hal ini membuat masyarakat Dusun Candih juga memaknai dirinya sebagai sesuatu yang berbeda dengan lingkungan sosialnya. 
Apalagi dengan adanya perlakuan-perlakuan dan pelabelan yang diberikan oleh masyarakat luar pada masyarakat Dusun Candih semakin membuat mereka merasa bahwa perbedaan itu nyata.

Kemudian dalam konsep identity, Goffman membagi identitas menjadi dua yakni self identity dan personal identity. Dalam konsep self identity, pemakanaan akan stigma yang ada melalui proses individu dalam memaknai diri sendiri. Hal ini memang memiliki kesamaan dengan konsep self. Padakonsep personal identity, masyarakat Dusun Candih memperoleh cap sebagai dusun begal yang berasal dari pemaknaan orang lain terhadap Dusun Candih. Dapat dicontohkan ketika seorang masyarakat asli Dusun Candih (A) pergi keluar dusun dan melakukan interaksi dengan (B) yang berasal dari dusun lain. Kemudian si B mengetahui bahwa si A bertempat tinggal di Dusun Candih yang memiliki cap sebagai “ Dusun Begal”. Maka secara otomotis B akan menanyakan apakah A tidak takut jika bepergian sendirian dan bahkan menyuruh A untuk tidak pulang terlalu malam agar terhindar dari aksi pembegalan. Dengan kesan pertama yang telah diberikan dapat disimpulkan bahwa orang tersebut memaknai bahwa Dusun Candih sebagai dusun yang rawan begal dan identik dengan kejahatan.

Dalam konsep stigma ini berkaitan erat dengan konsep personal identity sebab konsep tersebut adalah tentang bagaimana masyarakat Dusun Candih mendapat julukan sebagai "Dusun Begal" memaknai dirinya berdasarkan pemaknaan dari orang-orang di luar dusun. Hal tersebut yang kemudian menimbulkan pergesekan tentang bagaimana masyarakat Dusun Candih memaknai pelabelan yang terjadi pada dusunnya dengan pemaknaan dari orang luar atas diri mereka sendiri. Apabila hal ini dianalogikan, maka masyarakat memaknai adanya pelabelan atau cap yang diberikan sebagai suatu hal yang tidak usah dihiraukan keberadaannya dan tidak perlu dibesar-bersarkan serta tetap menjalani kehidupan sehari-sehari seperti biasanya. Sementara itu masyarakat luar menganggap bahwa Dusun Candih sebagai "Dusun Begal" sebagai sebuah ancaman yang harus diwaspadai keberadaannya. Persoalan yang terjadi dijadikan sebagai bahan gunjingan dan memandang bahwa masyarakat Dusun Candih sebagai pelaku kriminal meskipun kenyataannya tidak seperti itu. Stigma inilah yang pada akhirnya menyebabkan masyarakat Dusun Candih mengalami beberapa hambatan dalam menjalan kehidupan karena dibedakan dari kehidupan masyarakat normal pada umumnya.

\section{KESIMPULAN}

Bentuk-bentuk stigma yang diterima oleh masyarakat Dusun Candih terdiri dari stigma verbal dan non verbal. Stigma verbal diantaraya adanya sebutan atau julukan "Dusun Begal". 
Dalam hal ini stigma verbal yang diberikan ditujunkan pada citra dusun secara umum seperti karakteristik atau ciri dari dusun tersebut. Sedangkan stigma non verbal yang ada lebih pada perlakuan penolakan jika ada ajakan untuk berkunjung ke dusun tersebut, memandang rendah, atau bahkan menjelek-jelekkan masyarakat Dusun Candih. Berkaitan dengan respon atas stigma yang diberikan, terdapat beberapa pandangan dari masyarakat Dusun Candih. Bagi beberapa masyarakat adanya pelabelan "Dusun Begal" dan stigma yang melekat dianggap sebagai sesuatu hal yang wajar karena memang dusunnya dijadikan sebagai lokasi pembegalan. Anggapan tersebut dirasa menjadi hal yang lumrah sebagai respon masyarakat luas atas aksi pembegalan yang terjadi. Tak hanya itu, adanya label yang melekat dirasa membawa keuntungan pada keamanan bagi masyarakat asli Dusun Candih. Setelah adanya label tersebut, jarang terjadi kasus pencurian hewan ternak (sapi, kambing, dan ayam) diDusun Candih karena adanya anggapan bahwa maling segan dan takut jika mencuri di dusun tersebut. Namun menurut sebagian orang, pelabelan dan stigma yang melekat membawa dampak buruk. Stigma yang ada mengurangi rasa percaya orang luar pada masyarakat Dusun Candih yang berakibat pada penolakan-penolakan dan perlakuan diskriminatif.

\section{Kutipan Buku:}

\section{DAFTAR PUSTAKA}

Goffman, E. (1963). Stigma : Notes on the Management of Spoiled Identity. New York.

Ritzer, G. (2014). Teori Sosiologi: Dari Teori Sosiologi Klasik Sampai Perkembangan Mutakhir Teori Sosial Postmodern. Kreasi Wacana.

Sadewo, F. S. (2016). Petunjuk Praktis Untuk Peneliti Pemula. Universitas Negeri Surabaya: University Press.

Soyomukti, N. (2014). Pengantar Sosiologi: Dasar Analisis, Teori \& Pendekatan Menuju Analisi Masalah-Masalah Sosial, Perubahan Sosial, dan Kajian-Kajian Strategis (M. Sandra (ed.)). Ar-Russ Media.

\section{Kutipan Artikel Jurnal:}

Andina, E. (2015). Kejahatan Sadis Oleh Remaja: Studi Kasus Begal Sepeda Motordi Kota Depok. Aspirasi, 6(2), 1-14. 
Ardianti, A. (2017). Stigma Pada Masyarakat "Kampung Gila" di Desa Paringan Kecamatan Jenangan Kabupaten Ponorogo. Jurnal S1 Sosiologi Fisip Universitas Airlangga, 1-27.

Ayunani, R. D. (2016). Stigma Masyarakat Ponorogo Pada Penduduk Kampung Idiot.

Formaninsi, R. (2014). Stigma Masyarakat Terhadap Keluarga Pelaku Pembunuhan.

Goffman, E. (1963). Stigma : Notes on the Management of Spoiled Identity. Simon \& Schuster Inc.

Hajas, M. (2019). Penerimaan Masyarakat Terhadap Mantan Narapidana Begal Di Kota Makassar.

Hendriana, R., Yuris P.S., D. P., \& Tri Utami, N. A. (2016). PENANGGULANGAN KEJAHATAN BEGAL DI POLRES BANYUMAS (Dalam Perspektif Kriminologi dan Viktimologi). Jurnal Idea Hukum, 2(1). https://doi.org/10.20884/1.jih.2016.2.1.29

Millah, I. A. (2020). Penanggulangan Kejahatan Di Masa Pandemi Covid-19(Dalam Perspektif Kriminologi Dan Viktimologi). Jurnal Komunikasi Hukum (JKH), 6(2), 2356-4164. https://mediaindonesia.com/read

Muhammad, F. (2015). Tinjauan Kriminologis Tentang Kejahatan Begal YangMenggunakan Senjata Tajam. 61-68.

Ramadhan, A. A. (2020). Agama dan tindak kejahatan: studi kasus kriminal Begal di Bangkalan Madura. http://digilib.uinsby.ac.id/43290/

Ricardo, P. (2010). Upaya Penanggulangan Penyalahgunaan Narkoba Oleh Kepolisian (Studi Kasus Satuan Narkoba Polres Metro Bekasi). Indonesian Journal of Criminology, 6(3), $232-245$.

Sadewo, F. S. (2016). Petunjuk Praktis Untuk Peneliti Pemula.

Soyomukti, N. (2014). Pengantar Sosiologi: Dasar Analisis, Teori \& Pendekatan Menuju Analisi Masalah-Masalah Sosial, Perubahan Sosial, dan Kajian-Kajian Strategis (M. Sandra (ed.)). Ar-Russ Media. 
Tola, S. F., \& Suardi, S. (2017). Begal Motor Sebagai Perilaku Menyimpang. Equilibrium: Jurnal Pendidikan, 4(1). https://d oi.org/10.26618/equilibrium.v4i1.481

\section{Kutipan Website:}

Deny Prastyo Utomo, 2019. 4 Begal yang Rampas Motor Mahasiswa Bangkalan Madura Diringkus. https://news.detik.com/berita-jawa-timur/d-4627189/4-begal-yang-rampasmotor-mahasiswa-di-bangkalan-madura-diringkus

Mata Madura, 2019. UTM dan Sarang Begal diBangkalan. https://matamaduranews.com/utmdan-sarang-begal-di-bangkalan/

MediaMadura.com, 2018. Melintasi Daerah Rawan Begal di Bangkalan. https://kumparan.com/mediamadura/melintasi-daerah-rawan-begal-di-bangkalan

Polres Bangkalan, 2021. Dalam Kurun 7 Hari, 8 Kasus Kriminal Berhasil Diungkap Satreskim Polres Bangkalan. https://humas.polri.go.id/2021/01/08/dalam-kurun-7-hari-8-ka suskriminal-berhasil-diungkap-satreskrim-polres-bangkalan/ 